\title{
PEMANFAATAN INDEKS VEGETASI UNTUK ESTIMASI KANDUNGAN KALIUM PADA TANAMAN NANAS (Ananas comosus) MENGGUNAKAN UAV (Unmanned Aerial Vehicle) DI PT. GREAT GIANT PINEAPPLE, LAMPUNG
}

\section{Utilization of Vegetation Index for Estimation of Potassium Content in Pineapple Plants (Ananas comosus) Using UAV (Unmanned Aerial Vehicle) in PT. Great Giant Pineapple, Lampung}

\author{
Dita Khairunnisa*, Mochtar Lutfi Rayes, Christanti Agustina \\ Jurusan Tanah, Fakultas Pertanian, Universitas Brawijaya Jl. Veteran No.1 Malang 65145 \\ *Penulis korepondensi: ditakhairunnisa@ub.ac.id
}

\begin{abstract}
PT Great Giant Pineapple (PT. GGP) is the largest pineapple production company in Indonesia. One of the nutrients that pineapple plants really need is potassium $(\mathrm{K}) . \mathrm{K}$ plays a key role in carbohydrate metabolism and transport of photosynthates from source to sink. Remote sensing technology has been developed to estimate nutrient status, one of which is using an Unmanned Aerial Vehicle (UAV). This study aims to estimate the $\mathrm{K}$ nutrient content in pineapple plants using vegetation indexes in the form of NDVI (Normalized Difference Vegetation Index), SAVI (Soil Adjusted Vegetation Index), and OSAVI (Optimized of Soil Adjusted Vegetation Index). The research was carried out by taking aerial photographs and samples of pineapple plants in the 5 months phase before forcing up to 2 months after forcing (F-5 to F + 2), laboratory analysis, statistical analysis, and making distribution maps. The results showed that the relationship between the vegetation index value and $\mathrm{K}$ plant was the strongest and most significant is in 1 month before forcing phase (F-1) with the same $\mathrm{r}$ value for the three indices vegetation $(\mathrm{r}=0.867)$. The results of the regression analysis between the NDVI, SAVI and OSAVI values with K plant were $75.17 \%, 75.18 \%$ and $75.17 \%$, respectively. The calculation of the $\mathrm{K}$ estimate using three methods yielded no different values. The validation results using a paired t-test ( $\mathrm{t}$ count -0.63 ; $\mathrm{t}$ table 2.31 ; $\mathrm{p}$-value 0.544 ) where the $\mathrm{K}$ content in the measured plants and the estimation results showed no significant difference with the measurement results.
\end{abstract}

Keywords: pineapple plant, potassium, $U A V$, vegetation index

\section{Pendahuluan}

Nanas (Ananas comosus L. Merr) merupakan komoditas buah yang penting untuk dikembangkan, karena berperan dalam perekonomian nasional seperti meningkatkan ekspor non migas, gizi masyarakat, pendapatan petani dan suatu alternatif diversifikasi usaha, serta penyerapan tenaga kerja dan dapat menumbuhkan usaha di pedesaan serta pemanfaatan tanah pekarangan dan lahan kering (Ardisela, 2010). Salah satu perusahaan yang bergerak di bidang ekspor produksi nanas kaleng adalah PT. Great Giant Pineapple (PT. GGP). PT. GGP telah mengekspor nanas lebih dari 50 negara dan menyuplai $15-20 \%$ total kebutuhan nanas dunia. PT. GGP memiliki kapasitas produksi nanas sebesar 500.000 ton/tahun untuk mencukupi kebutuhan ekspor dengan total luas lahan yang dimiliki saat ini \pm 32.000 ha.

Salah satu upaya yang dapat dilakukan untuk meningkatkan produktivitas nanas adalah melalui pemupukan. Unsur hara penting yang sangat dibutuhkan tanaman nanas dalam pertumbuhan tanaman, pembungaan, dan 


\section{Jurnal Tanah dan Sumberdaya Lahan Vol 8 No 1: 91-99, 2021 \\ e-ISSN:2549-9793, doi: 10.21776/ub.jts1.2021.008.1.12}

pembentukan buah adalah kalium. Tanaman nanas membutuhkan kalium sejumlah yang besar dalam metabolisme karbohidrat. Aktivitas fotosintesis akan berkurang ketika $\mathrm{K}$ menurun, sehingga menghasilkan penurunan pertumbuhan tanaman dan kualitas buah (Safuan et al., 2011). Kalium dapat meningkatkan rasa keasaman dan/atau manis, aroma, dan kekukuhan daging buah (Teixeira et al., 2011). Kebutuhan hara dapat terpenuhi dengan cara pemupukan, baik organik maupun anorganik. Komposisi pemberian pupuk harus disesuaikan dengan kebutuhan hara tanaman.

Luasnya lahan PT. GGP membutuhkan banyak waktu, tenaga, dan biaya dalam pemantauan status hara. Saat ini telah banyak dikembangkan teknologi pemantauan status hara secara tepat dan efisien menggunakan penginderaan jauh (remote sensing). Umumnya peneliti memanfaatkan citra satelit sebagai wahana untuk interpretasi kondisi permukaan bumi. Pada area yang sempit, penggunaan citra satelit yang memiliki resolusi rendah merupakan pilihan yang kurang tepat karena dapat menyebabkan ketidaksesuaian informasi antara pendugaan dan kondisi di lapangan. Perekaman kondisi permukaan bumi pada area yang sempit dilakukan dengan memanfaatkan Unmanned Aerial Vebicle (UAV). UAV dilengkapi kamera multispektral dimana kamera tersebut mempunyai band merah, hijau, biru (RGB) dan NIR (Near Infra Red) yang dapat digunakan untuk menghitung kehijauan tanaman (Shofiyanti, 2011).

Foto udara yang ditangkap melalui UAV ditransformasikan ke dalam indeks vegetasi. Indeks vegetasi yang digunakan yaitu Normalyzed Difference Vegetation Index (NDVI), Soil Adjusted $V$ egetation Index (SAVI), dan Optimized of Soil Adjusted Vegetation Index (OSAVI). Menurut Prasasli et al. (2004), NDVI merupakan indeks vegetasi yang digunakan untuk pengamatan vegetasi secara global dengan menggunakan perbedaan energi spektral yang dipantulkan oleh kanopi vegetasi pada panjang gelombang spektrum elektromagnetik merah dan inframerah dekat. Transformasi indeks vegetasi SAVI dikembangkan untuk meminimalkan pengaruh tanah pada spektral kanopi dengan memasukkan faktor penyesuaian tanah (L) ke dalam persamaan indeks vegetasi (Marzukhi et al., 2016). Menurut Rondeaux et al. (1996),
OSAVI digunakan untuk meningkatan sensitivitas variabilitas pigmen daun dan mengurangi kontribusi pantulan latar belakang tanah (L) yang berbeda dibandingkan SAVI.

Penelitian ini dilakukan untuk mengkaji pemanfaatan foto udara resolusi tinggi UAV menggunakan indeks vegetasi dalam rangka menduga kandungan unsur hara kalium pada tanaman nanas. Penerapan pertanian presisi menggunakan penginderaan jauh di PT. Great Giant Pineapple telah dilakukan. Namun sejauh ini belum adanya informasi mengenai pendugaan kandungan hara $K$ tanaman nanas menggunakan foto udara UAV dengan indeks NDVI, SAVI dan OSAVI. Maka penelitian ini perlu dilakukan sebagai landasan pertimbangan dalam manajemen pemupukan.

\section{Metode Penelitian}

\section{Tempat dan waktu penelitian}

Penelitian dilaksanakan di PT. Great Giant Pineapple Jalan Terbanggi Besar, Lampung Tengah, Lampung, Indonesia (Gambar 1). Survei lapangan dilaksanakan pada bulan Juli sampai dengan September 2019. Analisis kimia tanaman dilaksanakan pada bulan Juli sampai dengan Agustus 2019 di laboratorium sentral PT. Great Giant Pineapple. Analisis data dilaksanakan pada bulan Oktober 2019 sampai dengan Maret 2020.

\section{Alat dan bahan}

Alat yang dimanfaatkan dalam kegiatan penelitian ini meliputi software ArcGIS 10.3, software AgiSoft Photoscan, software QGIS 3.4.11, software SPSS 26, software Microsoft office 2016, Quest UAV, GCP (Ground Control Point), GPS (Global Position System), avenza maps, windsock, alat tulis, dan laptop. Bahan yang menunjang dalam penelitian ini berupa Peta observasi, foto udara UAV, dan sampel D-leaf.

\section{Rancangan penelitian}

Penelitian dilakukan pada 8 lokasi dengan perbedaan fase forcing yaitu pada 5 bulan sebelum forcing sampai 2 bulan setelah forcing (F-5 sampai $\mathrm{F}+2$ ). Forcing adalah teknik perangsangan pembungaan dengan memberi bahan kimia pada tanaman nanas agar perubahan pertumbuhan dari fase vegetatif ke generatif terjadi secara 
seragam. Metode survei yang digunakan yaitu grid kaku dengan penentuan titik pengambilan sampel secara random. Setiap lokasi dilakukan pengambilan sampel tanaman pada 35 titik pengamatan dengan 1 titik diambil sebanyak 6 tanaman nanas. Pada 35 titik pengamatan terbagi menjadi dua yaitu 26 titik digunakan untuk model dan 9 titik digunakan untuk validasi. Pembuatan peta observasi dilakukan menggunakan software ArcGIS 10.3.

\section{Pengambilan foto udara}

Pengambilan foto udara dilakukan dengan menerbangkan Quest UAV yang memiliki resolusi 20 megapixel dengan ukuran pixel 0.06 x $0.06 \mathrm{~m}^{2}$ pada ketinggian $120 \mathrm{~m}$ dari permukaan tanah. Penerbangan UAV dilakukan pada pukul sekitar 09.00 WIB dengan kondisi cuaca cerah dan kecepatan angin normal.
Sebelum melakukan penerbangan perlu meletakkan Ground Check Point (GCP) pada setiap sudut lokasi. GCP berfungsi sebagai titik ikat yang menghubungkan antara sistem koordinat peta dengan sistem koordinat foto yang diukur menggunakan Global Position System (GPS).

\section{Pengambilan sampel tanaman nanas}

Pengambilan sampel tanaman nanas dilakukan di 35 titik pengamatan. Tanaman nanas diambil secara utuh, namun yang digunakan sebagai bahan penelitian adalah d-leaf. D-leaf merupakan daun termuda di antara daun dewasa yang paling aktif secara fisiologis serta dapat digunakan untuk mengevaluasi pertumbuhan dan status nutrisi tanaman. Pengambilan sampel tanaman harus memperhatikan keseragaman kondisi fisik dari keenam tanaman nanas tersebut.

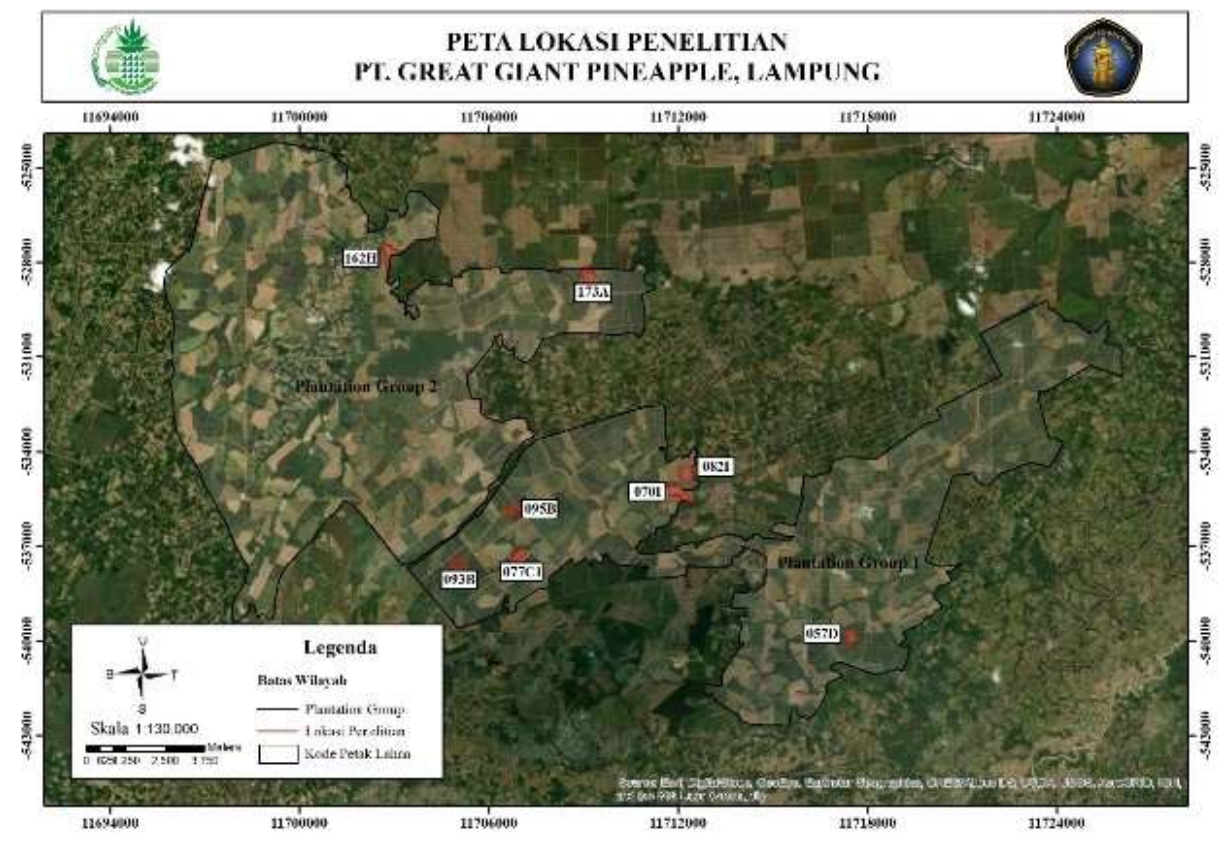

Gambar 1. Lokasi Penelitian.

\section{Pengolahan foto udara}

Foto udara diolah dengan menggunakan software Agisoft Photoscan Pro 1.3. Aplikasi Agisoft Photoscan Pro 1.3 memiliki fungsi untuk menggabungkan foto udara (mosaic) serta dapat mengolah data digital elevation model (DEM) dari foto udara yang telah digabungkan tersebut.
Langkah awal yang dilakukan adalah memasukkan foto yang akan diolah selanjutnya melakukan reference setting, camera calibration, serta align photo. Atur ketinggian kualitas foto menggunakan build mesh. Cari foto yang terdapat GCP dan buat marker pada titik tengah GCP. Selanjutnya adalah build dense clouds diikuti 


\section{Jurnal Tanah dan Sumberdaya Lahan Vol 8 No 1: 91-99, 2021 e-ISSN:2549-9793, doi: 10.21776/ub.jts1.2021.008.1.12}

dengan build texture, build DEM, dan build orthomosaic. Pengolahan foto udara diahkiri dengan melaukan export orthomosaic. Transformasikan foto udara ke dalam indeks vegetasi (NDVI, SAVI, dan OSAVI) menggunakan persamaan:

$$
\begin{array}{ll}
\text { NDVI } & =(\lambda \mathrm{NIR}-\lambda \mathrm{Red}) /(\lambda \mathrm{NIR}+\lambda \mathrm{Red}) \\
\text { SAVI } & (1+0,5)[(\lambda \mathrm{NIR}-\lambda \mathrm{Red}) /(\lambda \mathrm{NIR}+ \\
& \lambda \mathrm{Red}+0,5)] \\
\text { OSAVI } & (\lambda \mathrm{NIR}-\lambda \mathrm{Red}) /(\lambda \mathrm{NIR}+\lambda \mathrm{Red}+ \\
& 0,16)
\end{array}
$$

\section{Analisis laboratorium}

Analisis kandungan kalium pada tanaman nanas dilakukan menggunakan sampel d-leaf yang telah dikompositkan. Metode yang digunakan untuk penentuan kandungan kalium adalah Atomic Absorption Spektrophotometer (AAS) - wet ashing dengan menggunakan panjang gelombang 769,9 nm.

\section{Analisis statistik}

Foto udara yang telah di transformasikan ke dalam indeks vegetasi dan data hasil analisis laboratorium berupa persentase unsur kalium dianalisis korelasi dan regresi. Analisis korelasi memiliki rentang nilai -1 sampai 1 , digunakan untuk mengukur keeratan hubungan antara nilai indeks vegetasi dengan nilai kandungan kalium (\%). Analisis regresi dilakukan pada lokasi dengan nilai $r$ tertinggi, digunakan untuk mengukur besarnya hubungan antara nilai indeks vegetasi dengan nilai kandungan kalium (\%). Selanjutnya dilakukan uji T berpasangan untuk melihat kemiripan kandungan kalium tanaman nanas di lapangan (yang didapat dari analisis laboratorium) dengan kandungan kalium model estimasi.

\section{Pembuatan peta sebaran}

Peta sebaran kalium (\%) dibuat menggunakan software ArcGIS 10.3. Hal pertama yaitu memasukkan raster indeks vegetasi ke dalam persamaan regresi. Output raster kemudian dilakukan zonal statistic untuk melihat nilai estimasi $\mathrm{K}$ pada titik pengamatan. Interpretasi kelas kandungan kalium pada sub-plot produktif tanaman nanas (Sema et al., 2010) disajikan pada Tabel 1. Lakukan pengkelasan menggunakan properties, symbology, pilih stretched, kemudian atur interval sesuai dengan jumlah kelas pada Tabel
1. Membuat label sesuai dengan kelas kandungan kalium. Tahap terakhir, layout peta sebaran dan pastikan peta memuat seluruh informasi yang dibutuhkan.

Tabel 1. Interpretasi kelas kandungan kalium pada sub-plot produktif tanaman nanas.

\begin{tabular}{cc}
\hline Interval Kalium (\%) & Kelas \\
\hline$<1,23$ & Sangat Rendah \\
$1,23-1,41$ & Rendah \\
$1,42-1,60$ & Sedang \\
$1,61-1,79$ & Tinggi \\
$>1,79$ & Sangat Tinggi \\
\hline
\end{tabular}

\section{Hasil dan Pembahasan}

\section{Kondisi umum wilayah}

PT. Great Giant Pineapple berlokasi di Jalan Raya Arah Menggala Km. 77, Terbanggi Besar, Lampung Tengah. Secara geografis terletak pada

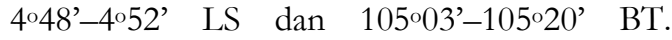
Lampung tengah merupakan wilayah dengan bentuk lahan dataran aluvial yang dipengaruhi oleh aliran sungai Way Sekampung, Way Tulangbawang, dan Way Mesuji. Ketinggian Lampung Tengah berkisar antara 25-75 mdpl dan kemiringan yang relatif datar yaitu 0-3\% (BAPPEDA, 2012). Berdasarkan data dari stasiun meteorologi pertanian khusus (SPMK), PT. GGP berada pada ketinggian $46 \mathrm{~m} \mathrm{dpl}$, jumlah curah hujan rata-rata dalam 10 tahun terakhir sebesar $1.969,47 \mathrm{~mm} /$ tahun, dengan rata-rata suhu minimum $2,5^{\circ} \mathrm{C}$ dan maksimum $33^{\circ} \mathrm{C}$. Jenis tanah PT. Great Giant Pineapple didominasi oleh tanah Ultisol. Ultisols memiliki bahan induk tuf masam, sehingga membuat tanahnya bersifat masam dan miskin unsur hara, kejenuhan basa, kapasitas tukar kation dan kandungan bahan organik rendah (Prasetyo dan Suriadikarta, 2006).

\section{Kandungan hara kalium tanaman nanas}

Nilai kandungan kalium pada tanaman nanas berkisar antara 0,84\%-2,18\% (Gambar 2). Kandungan kalium memiliki pola yang tidak menentu. Tanaman nanas pada fase sebelum forcing memiliki kandungan hara kalium lebih tinggi dibandingkan fase setelah forcing. Pengurangan pemberian pupuk pada fase 
setelah forcing dilakukan untuk menghentikan fase vegetatif ke generatif. Pada keadaan ini, akan terjadi mobilisasi hara dari daun ke organ reproduktif, sehingga menyebabkan kandungan hara daun menurun drastis (Wiraatmaja, 2016).

\section{Hubungan nilai indeks vegetasi dengan kandungan $K$}

Kalium tanaman nanas (\%) dengan indeks vegetasi (NDVI, SAVI, OSAVI) memiliki hubungan yang sedang hingga sangat kuat, koefisien korelasi (r) berkisar antara 0,452 0,867 . Hubungan paling kuat dan nyata terjadi pada fase 1 bulan sebelum forcing (lokasi 093B) yaitu $r=0,867$, sehingga analisis regresi hanya dilakukan pada lokasi 093B. Nilai r pada indeks vegetasi NDVI, SAVI, dan OSAVI tidak memiliki perbedaan. Hasil uji regresi menghasilkan persamaan dan $\mathrm{R}^{2}$ yang berbeda berdasarkan tiga indeks vegetasi (NDVI, SAVI, dan OSAVI) untuk mengestimasi kalium pada tanaman nanas (Gambar 3).

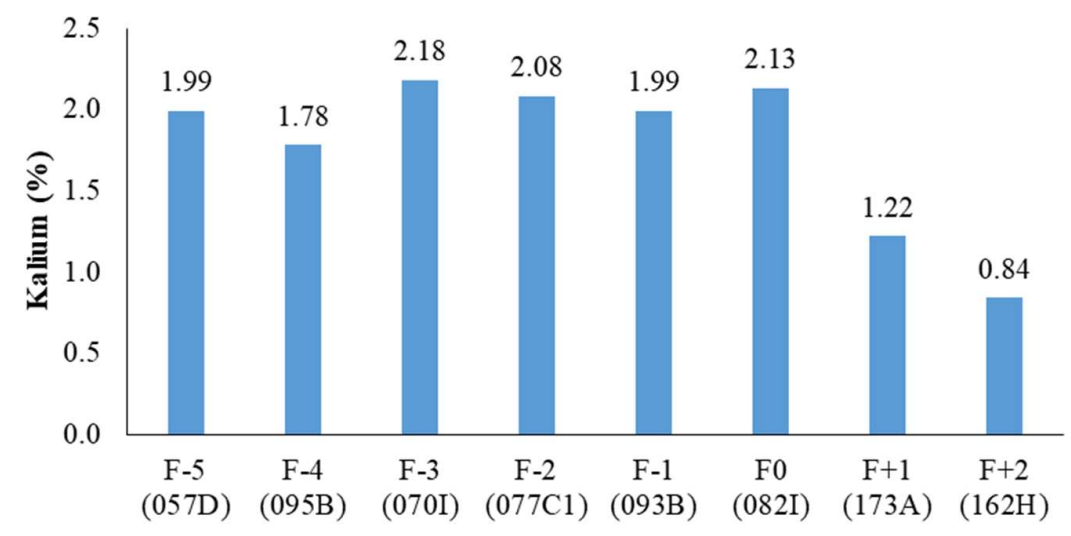

Fase sebelum \& setelah forcing (Lokasi Penelitian)

Gambar 2. Nilai kandungan kalium pada tanaman nanas.

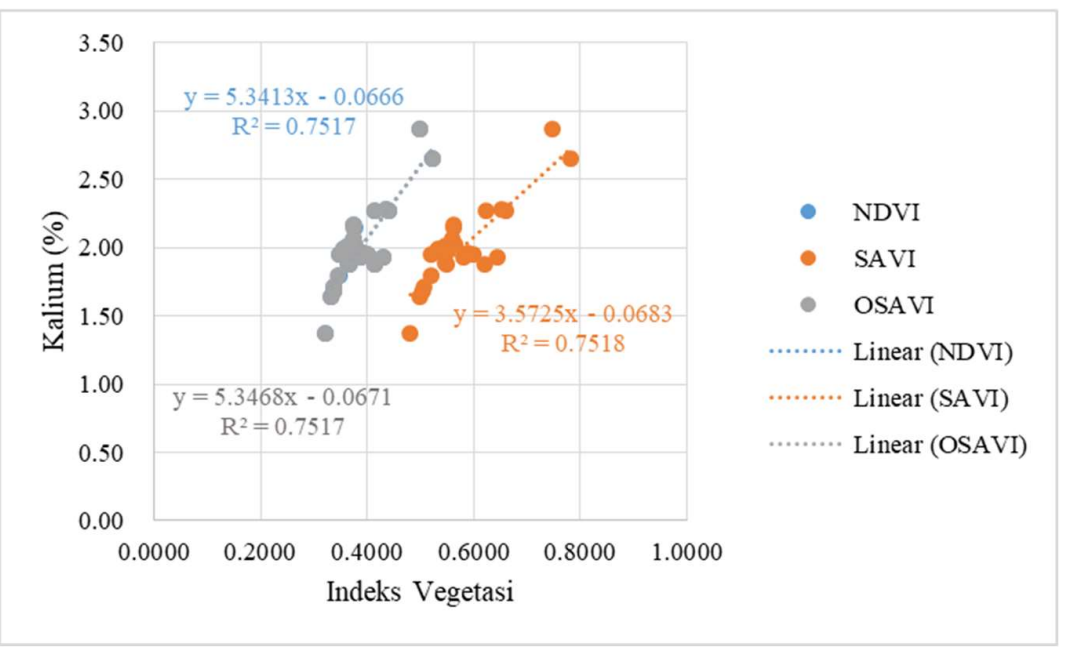

Gambar 3. Hasil uji regresi menghasilkan persamaan dan $\mathrm{R}^{2}$ yang berbeda berdasarkan tiga indeks vegetasi (NDVI, SAVI, dan OSAVI). 


\section{Jurnal Tanah dan Sumberdaya Lahan Vol 8 No 1: 91-99, 2021 \\ e-ISSN:2549-9793, doi: 10.21776/ub.jts1.2021.008.1.12}

Koefisien determinasi $\left(\mathrm{R}^{2}\right)$ NDVI, SAVI, dan OSAVI berturut-turut sebesar 75,17\%, 75,18\% dan $75,17 \%$. Nilai tersebut menjelaskan bahwa $75,17 \%$ - 75,18\% nilai $\mathrm{K}$ tanaman nanas di lapangan dapat dijelaskan oleh nilai piksel dari indeks vegetasi dan $24,12 \%-24,13 \%$ nilai $\mathrm{K}$ tanaman nanas dilapangan dijelaskan oleh faktor lain. Faktor lain yang mempengaruhi nilai $\mathrm{K}$ adalah kualitas foto udara dan teknik pengambilan sampel. Saat pengolahan foto udara, overlapping yang tidak tepat akan berpengaruh terhadap kualitas foto udara (orthomosaic). Overlap merupakan tumpang tindih foto, meliputi areal yang sama dalam satu jalur terbang. Foto udara tidak dapat di-overlapping dengan baik, akan terdapat beberapa bagian foto blur atau tidak dapat dijelaskan. Menurut Gularso et al. (2013), hasil foto udara tidak fokus (blur) kemungkinan dapat disebabkan oleh adanya foto yang tidak bertampalan secara maksimal, atau kondisi foto yang miring akibat posisi pesawat yang tidak stabil.

Faktor lainnya yang berpengaruh terhadap nilai $\mathrm{R}^{2}$ kandungan kalium dengan indeks vegetasi adalah variasi kandungan kalium antar sampel tidak terlalu tinggi. Pengambilan sampel seharusnya dipilih berdasarkan perbedaan warna kecerahan pada foto udara. Namun karena peneliti belum mengetahui kondisi aktual lahan, sehingga pengambilan sampel dilakukan menggunakan grid kaku dan penentuan titik pengambilan sampel menggunakan random sampling. Hasil analisis regresi menunjukkan bahwa $\mathrm{R}^{2}$ antara tiga indeks vegetasi (NDVI, SAVI, dan OSAVI) nilainya tidak berbeda jauh atau mendekati sama. Oleh karena itu, tidak dapat ditentukan indeks vegetasi terbaik dalam estimasi $\mathrm{K}$ menggunakan perbandingan nilai $\mathrm{R}^{2}$ saja. Pada dasarnya, ketiga indeks vegetasi ini memiliki persamaan indeks menggunakan band yang sama, merah (R) dan inframerah dekat (NIR). OSAVI lebih unggul dalam menduga unsur hara dibandingkan NDVI dan SAVI, karena persamaan OSAVI terdapat konstanta L $(0,16)$ yang dapat dipakai diberbagai kerapatan vegetasi. Konstanta $\mathrm{L}$ berfungsi untuk menekan pengaruh latar belakang tanah terhadap tingkat kecerahan kanopi. Huete (1988) menjelaskan bahwa konstanta L pada SAVI dibedakan pada kerapatan vegetasi, $\mathrm{L}=1$ untuk menganalisis vegetasi kerapatan rendah, $\mathrm{L}=0,5$ untuk kerapatan vegetasi menengah, dan $\mathrm{L}=0,25$ untuk kerapatan vegetasi tinggi. Penemu OSAVI (Rondeaux, 1996) menjelaskan bahwa konstanta L $(0,16)$ pada OSAVI dapat dipakai untuk analisis pada berbagai kerapatan vegetasi.

\section{Estimasi kandungan K menggunakan persamaan regresi}

Persamaan regresi berdasarkan masing-masing indeks vegetasi digunakan untuk membuat peta estimasi $\mathrm{K}$ pada tanaman nanas. Peta estimasi $\mathrm{K}$ berdasarkan NDVI, SAVI, dan OSAVI menunjukkan $\mathrm{K}$ tanaman nanas berkisar antara berkisar antara 1,65\%-2,73\% (Gambar 4 sampai 6). Daerah berwarna hijau menunjukkan kandungan $\mathrm{K}$ berada pada kelas tinggi (1,61\%$1,79 \%)$ hingga sangat tinggi $(>1,79 \%)$. Salah satu sifat kimia tanah Ultisol adalah kandungan hara yang dimiliki rendah. PT. Great Giant Pineapple telah melakukan tindakan ekstra untuk memenuhi kebutuhan hara $\mathrm{K}$ dengan pemberian pupuk $\mathrm{K}_{2} \mathrm{SO}_{4}$ dan $\mathrm{KCl}$ secara intensif pada tiap bulannya. Teixeira et al. (2011) menjelaskan bahwa pengaruh sumber yang berbeda pada pasokan kalium terhadap tanaman nanas tidak berbeda secara signifikan.

Kandungan kalium daun meningkat dengan aplikasi pupuk $\mathrm{K}$, terlepas dari sumber $\mathrm{K}$ dalam tanah. Pemberian kalium sulfat $\left(\mathrm{K}_{2} \mathrm{SO}_{4}\right)$ diperlukan stomata tanaman agar berfungsi secara normal, meningkatkan penggunaan fosfor, besi, dan unsur lainnya, serta memperbaiki kualitas buah. Tanaman nanas yang diberi pupuk $\mathrm{K}_{2} \mathrm{SO}_{4}$ (lengkap atau dikombinasikan dengan $\mathrm{KCl}$ ) memperlihatkan hasil yang lebih baik dibandingkan dengan hanya pemberian $\mathrm{KCl}$. Hussain et al. (2013) menyatakan pemberian pemupukan kalium meningkatkan pertumbuhan dan hasil tanaman. Menurut Sema et al. (2010), berdasarkan kelas nutrisi kalium pada sub-plot produktif tanaman nanas, nilai kandungan $\mathrm{K}$ pada fase 1 bulan sebelum forcing (lokasi 093B) telah memenuhi standar kecukupan kalium dalam tanaman. Teixeira et al. (2009) menjelaskan bahwa konsentrasi minimal dan maksimal kalium dalam tanaman nanas adalah $0,61 \%$ dan 3,04\%. Data tersebut merupakan data dari 104 peneliti terkait nutrisi dalam daun tanaman nanas $S$ mooth cayenne. Oleh karena itu, tanaman nanas tetap perlu dilakukan pemupukan dengan memperhatikan kebutuhan kalium pada tanaman nanas. 
Jurnal Tanah dan Sumberdaya Lahan Vol 8 No 1: 91-99, 2021 e-ISSN:2549-9793, doi: 10.21776/ub.jts1.2021.008.1.12

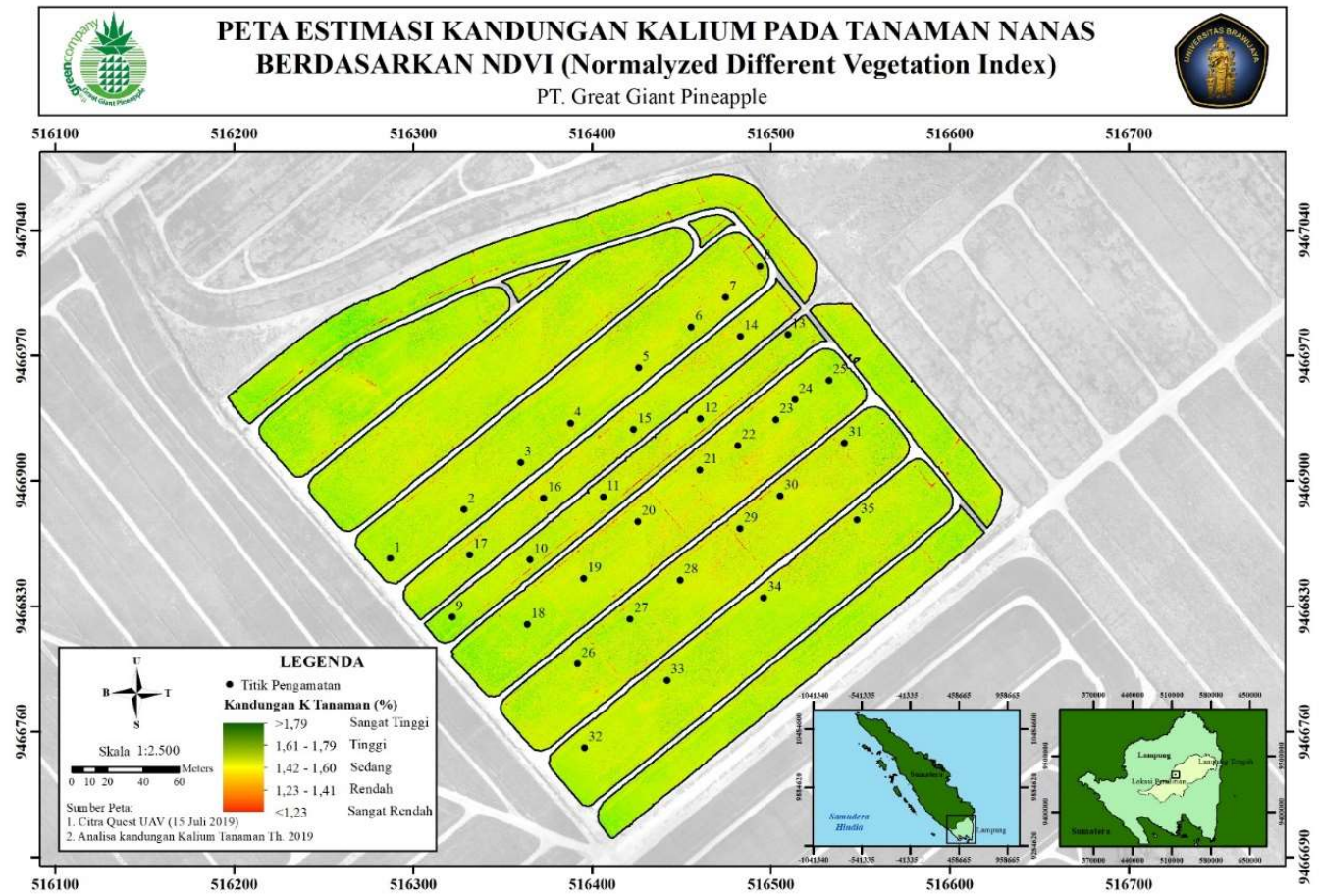

Gambar 4. peta estimasi kandungan $\mathrm{K}$ tanaman nanas berdasarkan NDVI..

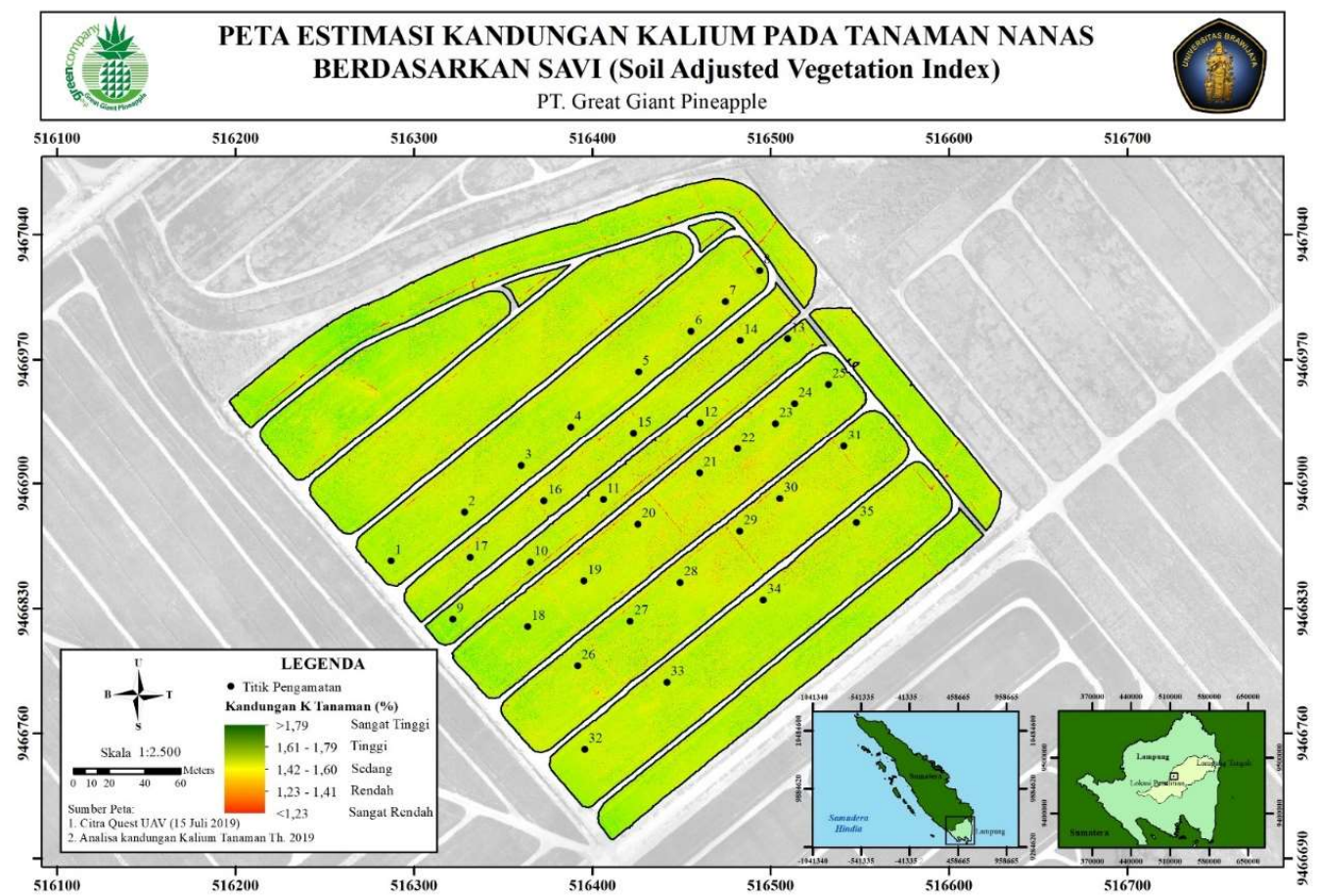

Gambar 5. Peta estimasi kandungan K tanaman nanas berdasarkan SAVI. 


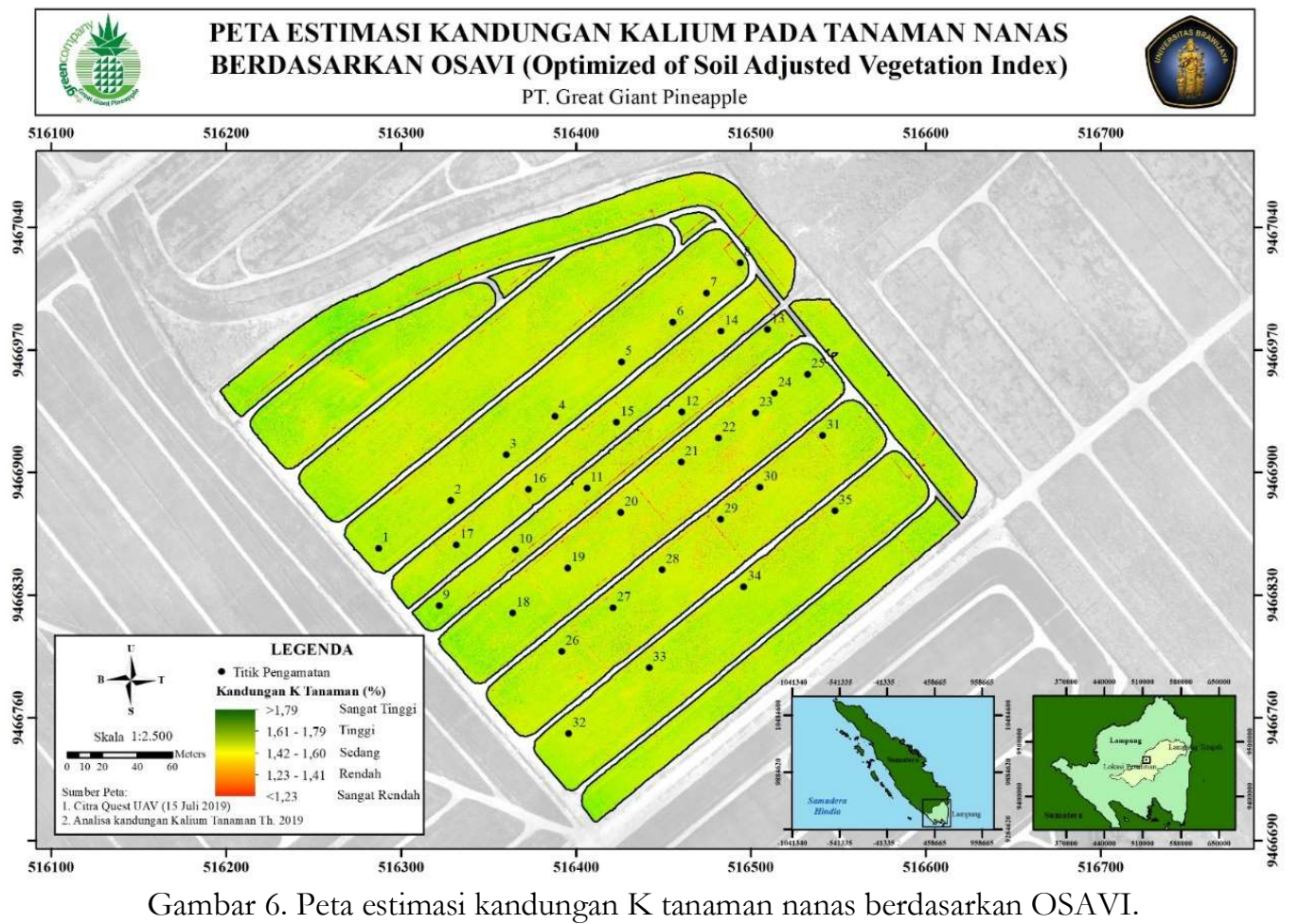

\section{Validasi hasil estimasi $K$ dengan hasil pengukuran $K$ di lapangan}

Data hasil pengukuran $\mathrm{K}$ di lapangan memiliki rata-rata sebesar $1,9645 \%$, sedangkan data hasil estimasi $\mathrm{K}$ menggunakan persamaan regresi NDVI, SAVI, dan OSAVI, memiliki nilai ratarata yang sama sebesar 2,1029\%. Model estimasi indeks vegetasi NDVI, SAVI, dan OSAVI memiliki t-hitung, t-tabel, dan p-value yang sama (t-hit: -0,63; t-tabel: 2,31; p-value: 0,544). Data menunjukkan t-hitung $<\mathrm{t}$-tabel dan $\mathrm{p}$-value $>\alpha$ $(0,05)$ mengartikan bahwa model estimasi dapat diterima, tidak ada perbedaan yang signifikan antara nilai estimasi $K$ menggunakan indeks vegetasi dengan nilai $K$ tanaman nanas di lapangan.

\section{Kesimpulan}

Kandungan kalium tanaman nanas pada fase 5 bulan sebelum focing hingga 2 bulan setelah forcing ( $\mathrm{F}-5$ hingga $\mathrm{F}+2$ ) berkisar antara 0,84\%-2,18\%, berada pada kelas kandungan $\mathrm{K}$ sangat rendah hingga sangat tinggi. Indeks vegetasi dengan $\mathrm{K}$ tanaman (\%) memiliki hubungan sedang hingga sangat kuat $(\mathrm{r}=0,452-0,867)$. Persamaan estimasi $\mathrm{K}$ dibuat pada fase 1 bulan sebelum forcing (lokasi 093B) dengan nilai $r$ tiga indeks vegetasi sama yaitu $r=0,867$ dan $R^{2}$ NDVI, SAVI, dan OSAVI berturut-turut sebesar 75,17\%, 75,18\%, dan $75,17 \%$. Hasil uji $T$ berpasangan menjelaskan bahwa tidak ada perbedaan yang signifikan antara nilai estimasi $\mathrm{K}$ menggunakan indeks vegetasi (NDVI, SAVI, dan OSAVI) dengan nilai $\mathrm{K}$ tanaman nanas di lapangan.

\section{Ucapan Terima Kasih}

Penulis menyampaikan ucapan terimakasi kepada PT. Great Giant Pineapple Jalan Terbanggi Besar, Lampung Tengah, atas dukungan pelaksanaan penelitian ini.

\section{Daftar Pustaka}

Ardisela, D. 2010. Pengaruh dosis Rootone-f terhadap pertumbuhan crown tanaman nenas (Ananas comosus (L.) Merr). Jurnal Agribisnis dan Pengembangan Wilayah. 1 (2): 48-62. 


\section{Jurnal Tanah dan Sumberdaya Lahan Vol 8 No 1: 91-99, 2021 e-ISSN:2549-9793, doi: 10.21776/ub.jts1.2021.008.1.12}

BAPPEDA. 2012. Draf Buku Putih Sanitasi. Pokja Percepatan Pembangunan Sanitasi Permukiman (PPSP) Kabupaten Lampung Tengah.

Gularso, H., Subiyanto, S. dan Sabri, L.M. 2013. Tinjauan pemotretan udara format kecil menggunakan pesawat model Skywalker 1680. Jurnal Geodesi Undip. 2 (2): 78-94.

Huete, A.R. 1988. A Soil-Adjusted Vegetation Index (SAVI). Remote Sensing of Environment. 25 (3): 295-309.

Hussain, Z., Khattak, R.A., Irshad, M. and Eneji, A.E. 2013. Ameliorative effect of potassium sulphate on the growth and chemical composition of wheat (Triticum aestivum L.) in salteffect soils. Journal of Soil Science and Plant Nutrition 13(2): 401-415.

Marzukhi, F., Elahami, A.L. and Bohari, S.N. 2016. Detecting nutrients deficiencies of the oil palm tress using remotely sensed data. IOP Conf. Series: Earth and Environmental Science 37: 111.

Prasasli, Indah, dan Sambodo, K.A. 2004. Pengkajian nilai indeks vegetasi data MODIS dengan menerapkan beberapa algoritma pengolahan data indeks vegetasi. Jurnal Penginderaan Jauh dan Pengolahan Data Citra Digital 1(1): 20-34.

Prasetyo, B.H dan Suriadikarta, D.A. 2006. Karakteristik, potensi, dan teknologi pengelolaan tanah Ultisol untuk pengembangan pertanian lahan kering di Indonesia. Jurnal Litbang Pertanian 25 (2): 39 - 46.
Rondeaux, G., Steven, M. and Baret, F. 1996. Optimization of Soil-Adjusted Vegetation Indices. Remote Sensing of Environment 55: 95-107.

Safuan, L.O., Poerwanto, R., Susila, A.D. and Sobir. 2011. The effect of soil potassium status on the growth and production of pineapple. Jurnal Agronomi 39 (1): 56-61.

Sema, A., Maiti, C.S., Singh, A.K. and Bendangsengla, K. 2010. DRIS nutrient norms for pineapple on Alfisols of India. Journal of Plant Nutritions 33(9): 1384 - 1399.

Shofiyanti, R. 2011. Teknologi pesawat tanpa awak untuk pemetaan dan pemantauan tanaman dan lahan pertanian. Informatika Pertanian 20(2): 5864.

Teixeira, L.A.J., Quaggio, J.A. and Zambrosi, F.C.B. 2009. Preliminary dris norms for 'Smooth Cayenne' pineapple and derivation of critical levels of leaf nutrient concentrations. Acta Horticulturae 822: 131-138.

Teixeira, L.A.J., Quaggio, J.A., Cantarella, H. and Mellis, E.V. 2011. Potassium fertilization for pineapple: effects on plant growth and fruit yield. The Revista Brasileira de Fruticultura 33 (2): 618626.

Wiraatmaja, W. 2016. Pergerakan Hara Mineral dalam Tanaman. Bahan Ajar. Fakultas Pertanian, Universitas Udayana: Denpasar. 